\title{
ROLA KRAJOZNAWSTWA I TURYSTYKI W INTEGRACJI SPOŁECZNEJ OSÓB Z NIEPEŁNOSPRAWNOŚCIĄ
}

\section{Wprowadzenie}

W ostatnich latach wiele mówi się o niepełnosprawności. Od dawna nie jest to już temat tabu, a osoby z niepełnosprawnością śmiało biorą czynny udział w życiu politycznym i społecznym. Widoczne są w przestrzeni publicznej i mało kto ośmieliłby się oficjalnie odmówić im prawa do korzystania z możliwości, jakie daje współczesny świat. Czym innym jest jednak oficjalna odmowa, a czym innym - codzienna, nieoficjalna dyskryminacja. W dzisiejszych czasach widać zdecydowane dążenie do tego, by niepełnosprawność nie była przeszkodą w prowadzeniu udanego, satysfakcjonującego życia.

Autorka artykułu podejmuje temat turystyki i krajoznawstwa w kontekście włączania osób z niepełnosprawnością w otaczające je środowisko społeczne, gdyż uznaje, że nie został on jeszcze wyczerpany.

\section{Integracja społeczna a niepełnosprawność}

Hasło „integracja społeczna” często kojarzy się z niepełnosprawnością, grupami osób wykluczonych bądź starszych. Z założenia istnieje jakaś mniejszość, słabsza grupa, której trzeba pomóc, czy to w dopasowaniu się do społecznych wymagań, czy to w jakiś sposób wpływając na środowisko, aby zaakceptowało tę słabszą mniejszość, razem z jej wyjątkowością i szczególnymi potrzebami. Z jednej strony dąży się do tego, żeby grupa ta miała swoje miejsce w społeczeństwie, $\mathrm{z}$ drugiej jednak - podkreśla się jej słabość. Tego typu podejście może być więc głęboko krzywdzące dla 
wspomnianych grup i prowadzić do powielania szkodliwych stereotypów. Koncentracja na tym, żeby proces integracji społecznej postępował możliwie jak najszybciej, jest istotną częścią wielu strategii polityki społecznej.

\section{Dotychczasowe działania na rzecz rozwoju turystyki i krajoznawstwa dla osób z niepełnosprawnością}

Turystyka osób z niepełnosprawnością jest zagadnieniem często poruszanym - nie tylko w kręgach naukowych. Jest to temat ważny i w związku z tym pojawia się wiele nowych publikacji. W ciągu ostatnich kilkunastu lat wydano monografie dotyczące działań podejmowanych na rzecz rozwoju turystyki i krajoznawstwa osób z niepełnosprawnością. Warto wymienić takie tytuły, jak:

- Turystyka i rekreacja ludzi niepetnosprawnych (Łobożewicz, 2000a),

- Krajoznawstwo i turystyka osób niepetnosprawnych (Midura, Żbikowski, 2005),

- Rola krajoznawstwa i turystyki w życiu osób niepełnosprawnych (Stasiak, 2008),

- Turystyka i krajoznawstwo niepełnosprawnych, czyli „Wędrować każdy może”. Wybrane aspekty (Kuleczka, 2008),

- Osoby niepetnosprawne w turystyce (Ziółkowski, 2010).

Od czasu wydania tych pozycji minęło już kilka lat, ale temat pozostaje nadal aktualny. Na wielu uczelniach studenci kierunków turystycznych uczęszczają na wykłady dotyczące turystyki osób z niepełnosprawnością lub turystyki dostępnej, definiowanej jako:

forma turystyki, która wymaga współpracy między interesariuszami w celu umożliwienia osobom z różnymi wymaganiami - związanymi z mobilnością wzrokiem, słuchem i wymiarem poznawczym - samodzielnego, godnego funkcjonowania. Taka współpraca polega na dostarczeniu uniwersalnie zaprojektowanych produktów turystycznych i usług oraz zapewnieniu uniwersalnie zaprojektowanego dostępu do przestrzeni (Darcy, Buhalis, 2011, za: Zajadacz, 2014a, s. 50).

Liczne fundacje, stowarzyszenia i towarzystwa organizują konferencje poświęcone dostosowywaniu przestrzeni do potrzeb osób z niepełnosprawnością. Wyjątkiem nie jest Polskie Towarzystwo Turystyczno-Krajoznawcze (PTTK), które od lat siedemdziesiątych programowo zajmuje się potrzebami turystów z niepełnosprawnością. Warto zauważyć, że temat ten był wielokrotnie podejmowany na sejmikach przed dotychczasowymi edycjami Kongresu Krajoznawczego PTTK (Śledzińska, 2012). 


\section{Korzyści wynikające z dostępności turystyki dla osób z niepełnosprawnością}

Zagadnienie turystyki osób z niepełnosprawnością ma dwa aspekty. Można zajmować się tematem barier i przeszkód, których zniwelowanie pozwoliłoby większej liczbie zainteresowanych, zostać czynnymi turystami. Można również skupić się na licznych korzyściach, które osoby z niepełnosprawnością odniosłyby dzięki uprawianiu turystyki. Pozytywnym aspektem są korzyści społeczne, a więc między innymi integracja społeczna osób z niepełnosprawnością. Partycypowanie w turystyce to udział w życiu społecznym, a więc realizacja społecznego celu turystyki, czyli tak naprawdę integracja osoby z niepełnosprawnością ze społeczeństwem (Łobożewicz, 2000). Dzięki temu osobom z niepełnosprawnością łatwiej funkcjonuje się wśród innych ludzi, a także wyrabiają one $\mathrm{w}$ sobie postawy społeczne i interpersonalne ułatwiające funkcjonowanie w społeczeństwie. Co ciekawe, dla osób z niepełnosprawnością funkcja integracyjna turystyki nie zawsze jest najważniejszą, rzadko kiedy też podejmują aktywność turystyczną ze względu na chęć integracji. Chcą oni raczej poznać nowe miejsca lub po prostu odpocząć (Kaganek, 2009).

\section{Ograniczenia $w$ integracji społecznej osób z niepełnosprawnością}

Mimo że poruszana przez autorkę artykułu problematyka była omawiana już wielokrotnie, to jednak w kwestii dostępności turystyki dla osób z niepełnosprawnością nie rozstrzygnięto wszystkich zagadnień. Pomimo powszechnej zgody, że każdy ma prawo do podróżowania, poznawania swojego kraju i korzystania z jego licznych zalet - w praktyce osoby z niepełnosprawnością często nie mają takiej możliwości. Wśród licznych ograniczeń wymieniana jest też bariera społeczna, wynikająca ze stosunku społeczeństwa, którego członkowie nieraz czują się niepewnie w kontaktach z osobami z niepełnosprawnością bądź wręcz unikają ich towarzystwa. Warto zaznaczyć, że zdarza się, iż to osoby z niepełnosprawnością - jako grupa - izolują się, bojąc się nieprzyjemności, niezrozumienia, nadmiernej opiekuńczości, protekcjonalnego traktowania, a nawet pogardy (Kaganek, 2009; Łobożewicz, 2000b). Gdyby nie niewłaściwe podejście społeczne oraz fizyczne niedostosowanie przestrzeni, każda osoba mogłaby w nim normalnie funkcjonować, bez względu na 
własny stan zdrowia. Rozumienie niepełnosprawności w tym modelu (nazywanym społecznym) nie jest więc cechą danej osoby, ale wynika $\mathrm{z}$ niedostosowanego środowiska, które $\mathrm{w}$ niewystarczającym stopniu uwzględnia potrzeby osób z niepełnosprawnością, czasem wręcz wykluczając je (Zajadacz, Śniadek, 2014).

\section{Rola turystyki i krajoznawstwa w procesie integracji i inkluzji społecznej osób z niepełnosprawnością}

Poruszane zagadnienie wydaje się niezwykle złożone i wielowątkowe - niełatwo bowiem zlikwidować wszystkie bariery utrudniające lub uniemożliwiające integrację społeczną osób z niepełnosprawnością. Udział $\mathrm{w}$ krajoznawstwie i turystyce nie zawsze jest możliwy w takim stopniu, w jakim być może życzyłyby sobie osoby z niepełnosprawnościa, a wpływ na to ma mnogość czynników. Pozostaje pytanie, czy naprawdę każda przeszkoda bądź bariera musi zostać usunięta, aby integracja społeczna następowała. Jeśli w mniej lub bardziej bezpośredni sposób oferta turystyczna skierowana jest do osób z niepełnosprawnością a nie do każdego, to korzysta z niej wtedy tylko określone grono odbiorców. Osoby biorące udział w turystyce tego typu są już niejako przygotowane, po pierwsze, na bardziej zróżnicowane pod względem sprawności towarzystwo, a po drugie, na konieczność dostosowania się do potrzeb osób o innych, być może większych, wymaganiach. Należy więc zastanowić się, czy oferta turystyczna kierowana do osób z niepełnosprawnością oraz ich towarzyszy faktycznie wspiera integrację społeczną tych pierwszych. Nadal pozostają oni w swoim kręgu znajomych, a spotkania na szlaku z innymi miłośnikami krajoznawstwa są przypadkowe.

Warto zwrócić uwagę na to, że osoby biorące udział w aktywności turystycznej skierowanej stricte do osób z niepełnosprawnością i ich towarzystwa mają mniejszą szansę spotkania osób nienależących jeszcze do grona tych, którzy swobodnie czują się w kontaktach z osobami z niepełnosprawnością. A biorąc pod uwagę, jak silne bywają uprzedzenia i ciążący stygmat niepełnosprawności, warto by każdy, kto może i chce, mógł brać udział w turystyce skierowanej do jak najszerszego grona klientów.

Należy pamiętać, że wspólne doświadczenia budują więź, nawet jeśli przeżywa sięje w różnym czasie i na różnych warunkach. W późniejszych 
kontaktach towarzyskich, rozmowach prywatnych czy pracy zawodowej, turysta z niepełnosprawnością będzie mógł podzielić się swoimi wrażeniami i doświadczeniami, znaleźć wspólny element, który złączy pozornie odrębne światy osób z niepełnosprawnością i tych bez niej. W ten sposób zbudować można zupełnie nową jakość kontaktu, w którym doświadczenie przebywania w tym samym miejscu uświadamia ludziom, że funkcjonują w obrębie jednego kręgu kulturowego, dzielą podobne przeżycia, odwiedzają te same miejsca, mimo że nie w ramach jednej wycieczki. Nawet jeśli konkretny szlak nie będzie dostępny, pozostają wrażenia z odwiedzenia i poznania danego regionu. Dla wielu osób wspólnota tego typu jest wystarczająca, ale można również spróbować planować aktywność tak, aby wszyscy, bez względu na niepełnosprawność lub jej brak, mogli wspólnie brać w niej udział.

Od pewnego czasu popularne staje się pojęcie inkluzji, czyli włączania. Jest to kontrpropozycja do pojęcia integracji, które ma to do siebie, że najpierw dzieli ludzi na grupy, które następnie próbuje zintegrować. Dzieje się to jednak przy faworyzowaniu grupy dominującej (głównego nurtu), brakuje zaś pomysłu, jak w rzeczywisty sposób grupy te z sukcesem połączyć (Vislie, 2003). Inkluzja, w przeciwieństwie do integracji, nie wyróżnia którejkolwiek z grup jako nienależącej do głównego nurtu. Według założeń tej teorii, niepełnosprawność jest obecnie opisywana w ten sam sposób co dyskryminacja ze względu na rasę, wiek czy religię, podczas gdy jej natura jest inna i inny też powinien być sposób jej traktowania (Winzer, 2009).

Warto zastanowić się, co znaczy, że osoba jest „zintegrowana” ze społeczeństwem lub „włączona” do niego i w jaki sposób proces ten przebiega. Osoby z niepełnosprawnością często traktowane są z góry, ich zmagania oraz problemy opisywane bywają przez główny nurt w sposób protekcjonalny, z pozycji wiedzy, przy czym zdarza się, że obserwowane zjawiska kreślą ludzie nieznający w pełni realiów życia osób z niepełnosprawnością. Oczywiście, nie dotyczy to wyłącznie badań nad turystyką osób z niepełnosprawnością, a perspektywa zewnętrzna jest cenna i pozwala często w bardziej obiektywny sposób przyjrzeć się sytuacji. Nie zmienia to jednak faktu, że nieraz trudne bywają starania, aby z jednej strony możliwie najpełniej włączyć osoby z niepełnosprawnością w życie społeczne, a z drugiej - by uparcie udawać, że ich niepełnosprawność nie istnieje. Być może warto zacząć od zauważenia konkretnej osoby, co doprowadzi nas do stwierdzenia, że inkluzja (oraz integracja) społeczna może być wyłącznie względna. To nie tak, że dana osoba jest całkowicie włączona bądź wyłączona społecznie. 
Ten sam człowiek może doskonale odnajdywać się w swoim środowisku szkolnym, zawodowym lub towarzyskim, a być zupełnie niezintegrowanym w innym, na przykład w grupie nieznanych sobie osób na wycieczce. Inkluzja społeczna to wynik złożonych interakcji pomiędzy daną osobą a czynnikami środowiskowymi. Niejednokrotnie człowiek dobrowolnie izoluje się od świata, na stałe albo czasowo, nie chce angażować się w życie społeczne, wybierając autonomię. Inkluzja społeczna to wiele złożonych interakcji między czynnikami środowiskowymi a cechami osobowości, które umożliwiają (Cobigo, Ouellette-Kuntz, Lysaght, Martin, 2012):

- dostęp do dóbr i usług publicznych;

- pełnienie docenianych i pożądanych ról społecznych, zależnych od wieku, płci i uwarunkowań kulturowych;

- uznanie za osobę godną zaufania i kompetentną do spełniania swojej roli w społeczności lokalnej;

- przynależność do sieci społecznej, w ramach której otrzymuje się i daje się wsparcie.

Osoby z niepełnosprawnością w procesie inkluzji społecznej zyskują możliwość uczestniczenia w pełni w życiu swojej społeczności na takim poziomie, który uważany jest za standardowy, normalny. Wówczas cechy związane $\mathrm{z}$ ich niepełnosprawnością są po prostu jednymi $\mathrm{z}$ wielu występujących $\mathrm{w}$ danym społeczeństwie i niczym się nie wyróżniają (Zajadacz, 2014).

W tym miejscu warto wrócić do koncepcji turystyki dostępnej, która może się przyczyniać do integracji społecznej osób z niepełnosprawnościa, szczególnie jeśli w ofercie uwzględniane są integracyjne zajęcia rekreacyjne (Kastenholz, Eusébio, Figueiredo, 2015). O włączaniu osób z niepełnosprawnością w zajęcia rekreacyjne pisała w Polsce Wolańska (2000). Stworzenie środowiska otwartego dla wszystkich chętnych pozwala na wydobycie potencjału osób w nim funkcjonującym, a każdy może rozwijać się na miarę swoich możliwości i uczestniczyć w dowolnej aktywności na tyle, na ile może i chce. Na tym właśnie polega włączanie, inkluzja. Zasada normalizacji zakłada, że osoba niepełnosprawna ma prawo żyć i funkcjonować w normalnym systemie społecznym - jest to założenie trudne w realizacji, choć słuszne w teorii (Wolańska, 2000). Warto jednak podjąć taki wysiłek, gdyż wspólna wycieczka to specyficzna okazja do nawiązywania relacji, w której kontakt z drugą osobą może być bliższy, bardziej otwarty. Emocje przeżywane wspólnie z towarzyszami wędrówek stanowią czynnik integrujący, sprzyjający budowaniu więzi międzyludzkiej (Zdebski, Gordon, 2005). 


\section{Razem czy osobno - oferta turystyczna dla osób z niepełnosprawnością}

Dla wielu osób różnica między „integracją" a „inkluzją” jest nikła, być może jest to rozróżnienie czysto teoretyczne, niemające efektywnego przełożenia na realne działania. Warto zastanowić się, co można zrobić, aby zarówno w oczach osób z niepełnosprawnością, jak i reszty społeczeństwa oba procesy przebiegały skutecznie i miały pozytywne rezultaty. Aby podczas korzystania z oferty turystycznej i krajoznawstwa osoba z niepełnosprawnością czuła się członkiem społeczności, a zarazem - żeby społeczność nie odbierała obecności tej osoby jako obciążenia, co niestety nieraz ma miejsce. Zdarza się, że dostosowanie tempa marszu do najwolniejszego piechura nie zawsze jest dla grupy przyjemne, nie mówiąc o zmianie trasy wycieczki ze względu na niedostępność architektoniczną konkretnego miejsca. Nie każdy cierpliwie wysłucha dokładnego opisu krajobrazu, zwłaszcza jeśli jest to opis uproszczony ze względu na obecność osób z niepełnosprawnością intelektualną w tym przypadku stygmatyzacja jest szczególnie silna. Jeżeli obecność osób z niepełnosprawnością w jakiś sposób sprawi, że dany wyjazd czy wyjście będą mniej atrakcyjne dla pozostałych osób, znajdziemy się de facto w punkcie wyjścia. Nikt bowiem nie będzie czuł się dobrze: ani osoby z niepełnosprawnością, dla których mogłaby być to okazja do włączenia się w życie społeczne, poznanie nowych osób, rozwój zainteresowań i osobisty, ani osoby pełnosprawne, które nie będą czuły się usatysfakcjonowane i może się zdarzyć, że nie będą więcej korzystały z takiej oferty turystycznej.

Należy również wziąć pod uwagę, iż nie ma nic złego w tym, że dla osób z niepełnosprawnością przygotowuje się oddzielną ofertę, uwzględniającą ich szczególną sytuację. Turnusy rehabilitacyjne są przykładem tego typu wyjazdów - można nawiązać tam kontakt z osobami z niepełnosprawnością, często określonego typu. Istnieją także wyjazdy turystyczne profilowane pod osoby z niepełnosprawnością. Dzięki takim zabiegom produkt turystyczny jest lepiej dostosowany do klienta, zwiększając tym samym szansę na wysokie zadowolenie odbiorcy.

\section{Podsumowanie}

Tytułując niniejszy tekst: „Rola krajoznawstwa i turystyki w integracji społecznej osób z niepełnosprawnością” autorka starała się wzbudzić refleksję dotyczącą tego, na ile rola ta jest pozytywna, a na ile negatywna. 
Warto bowiem zastanowić się, czego wymaga się od turystyki i krajoznawstwa. Jeśli tego, aby dobrze pełniły jedną ze swoich funkcji - czyli umożliwiały włączanie osób z niepełnosprawnością w życie społeczne, włączanie ich do społeczeństwa i dawanie poczucia bycia jego członkami, traktowanymi na równi z innymi - oznaczać to będzie, że nie myśli się o integracji postrzeganej w sposób tradycyjny, ale właśnie o włączaniu, inkluzji. Jest wiele dowodów na to, że środowisko osób związanych z turystyką i krajoznawstwem z pełną otwartością i zaangażowaniem podchodzi do wyzwań związanych z obsługą turysty z niepełnosprawnością. Jeśli ogólna dostępność stanie się normą nie trzeba będzie skupiać się na niepełnosprawności członków wycieczki, a raczej na tym, aby oferta turystyczna była atrakcyjna dla wszystkich turystów - niezależnie od stopnia niepełnosprawności bądź jego braku. To podejście wpisuje się w nurt turystyki dostępnej, o której była mowa wyżej.

\section{Bibliografia}

Cobigo, V., Ouellette-Kuntz, H., Lysaght, R., Martin, L. (2012). Shifting our conceptualization of social inclusion. Stigma Research and Action, 2 (2), 75-84. https://doi.org/10.5463/ sra.v1i3.45

Kaganek, K. (2009). Turystyka osób niepetnosprawnych w aspekcie wybranych uwarunkowań. Kraków: EAS.

Kastenholz, E., Eusébio, C., Figueiredo, E. (2015). Contributions of tourism to social inclusion of persons with disability. Disability and Society, 30 (8). https://doi.org/10.1080 /09687599.2015.1075868

Kuleczka, P. (red.) (2008). Turystyka i krajoznawstwo niepetnosprawnych, czyli „Wędrować każdy może...". Wybrane aspekty. Kalisz: Edytor.

Łobożewicz, T. (red.) (2000a). Turystyka i rekreacja ludzi niepetnosprawnych. Warszawa: Wyższa Szkoła Ekonomiczna w Warszawie.

Łobożewicz, T. (2000b). Bariery ograniczające udział ludzi niepełnosprawnych w turystyce i rekreacji oraz sposoby ich przezwyciężania. W: T. Łobożewicz (red.), Turystyka i rekreacja ludzi niepełnosprawnych (s. 49-55). Warszawa: Wyższa Szkoła Ekonomiczna w Warszawie.

Midura, F., Żbikowski, J. (red.) (2005). Krajoznawstwo i turystyka osób niepełnosprawnych (s. 11-15). Biała Podlaska: Wydawnictwo PWSZ im. Papieża Jana Pawła II.

Stasiak, A. (red.) (2008). Rola krajoznawstwa i turystyki w życiu osób niepetnosprawnych. Warszawa: Wydawnictwo PTTK „Kraj”.

Śledzińska, J. (2012). Turystyka osób niepełnosprawnych w Polskim Towarzystwie Turystyczno-Krajoznawczym. Niepetnosprawność - zagadnienia, problemy, rozwiazania, 2 (II), 81-103.

Vislie, L. (2003). From integration to inclusion: Focusing global trends and changes in the western European societies. European Journal of Special Needs Education, 18 (1), 17-35. https://doi.org/10.1080/0885625082000042294 
Winzer, M.A. (2009). From integration to inclusion: A history of special education in the $20^{\text {th }}$ Century. Washington, DC: Gallaudet University Press. https://doi.org/10.5860/ choice.47-5790

Wolańska, T. (2000). Rekreacja osób niepełnosprawnych. W: T. Łobożewicz (red.), Turystyka i rekreacja ludzi niepetnosprawnych (s. 86-97). Warszawa: Wyższa Szkoła Ekonomiczna w Warszawie.

Zajadacz, A. (2014a). Dostępność przestrzeni turystycznej w ujęciu geograficznym. Turyzm, 24 (1), 49-55.

Zajadacz, A. (2014b). Nastawienie przyszłych pracowników sektora usług turystycznych do niepełnosprawnych klientów. Studia przypadku z Polski i Rosji. W: Z. Młynarczyk, A. Zajadacz (red.), Uwarunkowania i plany rozwoju turystyki. Turystyka dostępna i humanistyczne aspekty turystyki (s. 18-44). Poznań: Bogucki Wydawnictwo Naukowe.

Zajadacz, A., Śniadek, J. (2014). Modele niepełnosprawności jako determinanty przeobrażeń struktury podażowej rynku turystycznego dostępnego dla osób niepełnosprawnych. W: Ewolucja podaży i popytu w turystyce (s. 208-230). Sucha Beskidzka: Wyższa Szkoła Turystyki i Ekologii.

Zdebski, J., Gordon, A. (2005). Integracyjna rola krajoznawstwa i turystyki osób niepełnosprawnych w Polskim Towarzystwie Turystyczno-Krajoznawczym. W: F. Midura, J. Żbikowski (red.), Krajoznawstwo i turystyka osób niepetnosprawnych (s. 11-15). Biała Podlaska: Wydawnictwo PWSZ im. Papieża Jana Pawła II.

Ziółkowski, R. (red.) (2010). Osoby niepełnosprawne w turystyce. Białystok: Oficyna Wydawnicza Politechniki Białostockiej.

\title{
ROLA KRAJOZNAWSTWA I TURYSTYKI W INTEGRACJI SPOŁECZNEJ OSÓB Z NIEPEŁNOSPRAWNOŚCIĄ
}

Abstrakt: W artykule przedstawiono problem integracji społecznej osób z niepełnosprawnością w kontekście turystyki i krajoznawstwa. Opisano dotychczasowe działania, podejmowane przez środowisko akademickie w celu porządkowania oraz upowszechniania wiedzy dotyczącej tego zjawiska. Następnie omówiono pojęcia integracji i inkluzji społecznej oraz korzyści, jakie przynosi włączenie turystyki i krajoznawstwa w oba wspomniane procesy. Przedstawiono również wątpliwości i trudności związane z organizacją wspólnych wyjazdów turystycznych dla osób z niepełnosprawnością i bez niej.

Słowa kluczowe: turystyka dostępna, krajoznawstwo, niepełnosprawność, integracja społeczna, inkluzja społeczna.

\section{THE ROLE OF TOURISM AND SIGHTSEEING IN THE SOCIAL INTEGRATION OF PEOPLE WITH DISABILITIES}

\begin{abstract}
This article presents the issue of the social integration of those with disabilities in the context of tourism. It briefly discusses the action taken so far by the academic community in order to systematise and disseminate knowledge about this phenomenon. Notions of social inclusion and integration, as well as the benefits of including tourism and sightseeing in both these processes, are discussed. In this part, doubts and difficulties connected with the organisation of joint tourist trips for those with and without disabilities were presented.
\end{abstract}

Keywords: accessible tourism, sightseeing, disability, social integration, social inclusion. 